\title{
1. The interdependence of issues relating to the universality, proliferation and costs of human rights
}

\section{Thomas Van Poecke, Marie Bourguignon, Jan Wouters and Koen Lemmens}

\subsection{INTRODUCTION}

The seventieth anniversary of the Universal Declaration of Human Rights (UDHR) took place at a time when human rights are under pressure. ${ }^{1}$ The reasons for this vary, from a lack of implementation and enforcement (e.g. in fragile states) ${ }^{2}$ to the challenges raised by new technologies (in particular artificial intelligence) ${ }^{3}$ they include the effects of austerity and/or neoliberal policies, ${ }^{4}$ a new rise in authoritarianism, ${ }^{5}$ the delegitimization of human rights in liberal democracies in times of populism and nationalism, ${ }^{6}$ as well as an apparent increasing popular scepticism about human rights. ${ }^{7}$ Accordingly, this

1 E.g., Statement by Special Procedures on the occasion of Human Rights Day, 10 December 2018: 'The resilience and relevance of the Universal Declaration of Human Rights after 70 Years in a time of closing borders and closing civic space', www.ohchr .org/EN/NewsEvents/Pages/DisplayNews.aspx?NewsID=23991\&LangID=E.

2 E.g., W Kälin, 'Late Modernity: Human Rights under Pressure?' 15 Punishment \& Society (2013) 397, 402-405.

3 E.g., MK Land and JD Aronson (eds), New Technologies for Human Rights Law and Practice (CUP 2018).

4 E.g., A Nolan (ed.), Economic and Social Rights after the Global Financial Crisis (CUP 2014).

5 E.g., A Muis and L van Troost (eds), Changing Perspectives on Human Rights: Will Human Rights Survive Illiberal Democracy? (Amnesty International Netherlands, March 2018), www.amnesty.nl/content/uploads/2015/10/illiberal-democracy-PDF $-20 \mathrm{mrt} . \mathrm{pdf}$ ?x10542.

6 E.g., D Celermajer and D Avnon, 'Human Rights under "Democratic" Pressure: Navigating a Path between Truth and Politics' (2019) 41 Human Rights Quarterly 672.

7 E.g., CIVICUS, 'State of Civil Society Report 2019: The Year in Review', March 2019, www.civicus.org/documents/reports-and-publications/SOCS/2019/state-of-civil 
anniversary presented itself as an opportunity to critically reflect on the UDHR and its legacy. Provocatively, we asked ourselves: 'Can we still afford human rights?' We aim to answer this question by critically assessing the sustainability and effectiveness of the UDHR and its legacy in light of some of the current criticisms of human rights. For reasons of feasibility, we brought down our quest for a critical reflection to the interaction between three frequently evoked issues that appear essential for such an assessment: the universality, the proliferation and the costs of human rights.

Accordingly, this volume is divided in three parts, respectively addressing the aforementioned themes. Every part is introduced by a contribution providing a general and thought-provoking overview of the relevant theme. Per theme, three additional contributions zoom in on more specific issues. As the themes of universality, proliferation and costs are closely intertwined, it happens that authors, while focusing on one of the three themes, also touch upon the other themes. In the first part of this chapter, we will outline the theoretical background of the three topics and their interdependence, single out their relation to the current debates on human rights, and succinctly frame the chapters of this volume in the context of the theoretical background. In the second part, this chapter brings together the essential findings of the contributions to this volume in order to address the interdependence of issues relating to the universality, proliferation and costs of human rights. We conclude by bringing together the authors' findings in a way that provides answers to the overall question asked by this volume.

\subsection{THEORETICAL BACKGROUND}

\subsubsection{Universality}

Since the drafting of the UDHR, the universality of human rights has been challenged continuously. Remarkably, this is increasingly also the case for people and governments of states that used to defend it. ${ }^{8}$ Kaplan (2018) usefully frames the issue by distinguishing between, on the one hand, 'thin societies', which are 'highly individualistic and value choice, fairness, justice and rights' and are 'based on maximizing individual freedom', and, on the other hand, 'thick societies', which are 'highly sociocentric and value order, tradi-

-society-report-2019_executive-summary.pdf noting as a trend in 2018: 'Civil society, acting on humanitarian impulses, confronts a rising tide of global mean-spiritedness, a public compassion deficit' (at 8). See also Kälin (n 2) 407-408.

$8 \mathrm{~T}$ Carothers and S Brechenmacher, Closing Space: Democracy and Human Rights Support Under Fire (Carnegie Endowment for International Peace 2014), https://carnegieendowment.org/files/closing_space.pdf, at 7. 
tion, duty sanctity, and purity' and are 'based on maximizing the robustness of relationships and institutions'. ${ }^{9}$ While thin societies tend to favour a (Western) universalist approach, thick societies - or thick communities within thin societies - generally take a more relativist approach to human rights. ${ }^{10}$ Even if the human rights 'gap between the West and the rest' should not be exaggerated, ${ }^{11}$ the 'thick-thin spectrum' is useful for our purposes, especially as it takes into account thick communities within thin societies.

Kaplan's analysis goes straight to the sustainability and effectiveness of the UDHR and its legacy. He states that increasingly, 'the stark difference between how thick and thin societies interpret human rights risks undermining the human rights regime's legitimacy and relevance as a multicultural, multinational project'. ${ }^{12}$ According to Kaplan, the UDHR embodies a 'flexible yet universal approach' that views human rights as universal, but accepts that 'they need to be implemented in a way that takes local social and political contexts into account, especially in thick societies and communities'. ${ }^{13}$ Similarly, Donnelly (2013) argues for a 'relative universalism' that entails 'universality only at the level of the concept', while the 'ways in which these rights are interpreted and implemented [...] are matters of legitimate variation' ${ }^{14}$ To 'close - or at least narrow - the gap between international human rights and non-Western societies', Brems advocates for an 'inclusive universality'. She stresses 'that human rights are not context-neutral', and proposes to accommodate particularist claims from people who experience a form of exclusion because they 'do not correspond to the implicit point of reference of human rights (a human being that is male and Western)' ${ }^{15}$ Overall, the 'unease about some elements of the human rights agenda' which 'extends across most of the non-Western world and encompasses many religious groups within Western countries' deserves more attention. ${ }^{16}$ In this light, Chapter 2 by Nick

9 SD Kaplan, Human Rights in Thick and Thin Societies: Universality without Uniformity (CUP 2018) 2-3, 15, 69-70.

$10 \quad$ Ibid., 4.

11 E Brems, Human Rights: Universality and Diversity (Nijhoff 2001) 357.

12 Kaplan (n 9) 185. See also 187.

13 Ibid., 5, 16-47, 185.

14 J Donnelly, Universal Human Rights In Theory and Practice (3rd edn, Cornell University Press 2013) 103.

15 E Brems, 'Reconciling Universality and Diversity in International Human Rights: A Theoretical and Methodological Framework and Its Application in the Context of Islam' (2004) Human Rights Review 5, 12. However, 'this should not be a one-way street' and such efforts 'should be matched by efforts inside societies to make those more receptive to human rights'; ibid. See also Brems (n 11) 295-339.

16 Kaplan (n 9) 6. 
Goetschalckx complements the universality debate and builds in particular on Donnelly's (early) work by arguing for a 'presumptive universalism'. ${ }^{17}$

To give effect to his 'flexible yet universal approach', Kaplan argues for a 'return to basics' in the form of a 'new global treaty on the core rights' that restores 'the overlapping consensus' on human rights as it existed at the time of the adoption of the UDHR. ${ }^{18}$ This treaty should reflect 'minimal universalism' and focus on a narrow set of rights that protect against the 'great evils of the human condition', the absence of which ensures a human condition of 'basic decency', ${ }^{19}$ and which are 'equally recognized across both thick and thin societies'. ${ }^{20}$ This proposition takes into account Brems' argument that gross human rights violations - 'attacks on the core of human rights' - should be excluded 'from the scope of the accommodation of particularist claims' ${ }^{21}$ Kaplan's suggested treaty should come 'with a robust enforcement mechanism'.22 In a similar vein, Chapter 3 by Konstantinos Magliveras advocates for a comprehensive global human rights treaty with a core part containing a certain minimum of protected rights, and optional protocols for specific rights or group rights, to be monitored by a single treaty body and an Assembly of States Parties.

To support his arguments, Kaplan notes that even 'the European human rights protection system [...] allows a significant degree of flexibility at times with regard to local context'. ${ }^{23}$ More particularly, its 'margin of appreciation doctrine' allows the European Court of Human Rights (ECtHR) 'to provide greater or lesser flexibility to countries to restrict or limit a particular right agreed to in an international agreement - in Europe's case, the European Convention on Human Rights [ECHR] - depending on the issues involved'. ${ }^{24}$ As Brems puts it, the 'margin of appreciation doctrine can be used to accommodate a wide range of particularity claims'. ${ }^{25}$ Kaplan argues that there is a 'need for greater use of the [...] doctrine, especially when applied to noncore

\footnotetext{
17 Cf. J Donnelly, 'Cultural Relativism and Universal Human Rights' (1984) 6 Human Rights Quarterly 400.

18 Kaplan (n 9) 7, 102, 132, 185.

19 WA Galston, The Practice of Liberal Pluralism (CUP 2004) 3, 189, 197-199.

20 Kaplan (n 9) 211-215. Others, like EA Posner, The Twilight of Human Rights Law (OUP 2014) 137-138, consider that the proposal to 'give priority to a narrow set of rights' leads to a dead end, as 'the relevant rights-enforcers cannot agree that a specific subset of rights are fundamental while the others are not'.

21 Brems (n 11) 320-322.

22 Kaplan (n 9) 213.

23 Ibid., 35.

24 Ibid.

25 Brems (n 11) 363.
} 
human rights in thick societies and communities'. ${ }^{26}$ In this light, Chapter 4 by Paul Lemmens considers the issue of universality from a European perspective, paying particular attention to the way in which the ECtHR deals with the issue. Chapter 5 by Johan Lievens and Nele Verbrugghe delves deeper into the matter with a case study on the recognition of same-sex relationships under the ECHR. Needless to say, the extent to which human rights can be realized universally is affected by the proliferation of human rights, an issue to which we turn now.

\subsubsection{Proliferation}

As Clément (2018) notes, there 'is a long history across disciplines of concerns surrounding the implications of rights inflation'. ${ }^{27}$ Pocklington (1982) has argued that 'the recent inflation of appeals to human rights is both philosophically indefensible and politically unwise'. ${ }^{28}$ According to Alston (1984), a proliferation of new rights without first giving 'adequate consideration to their desirability, viability, scope or form' would probably 'contribute to a serious devaluation of the human rights currency'. ${ }^{29}$ Gutmann (2001) has argued that the inclusion of 'rights that are not clearly necessary to protect the basic agency or needs or dignity of persons cheapens the purpose of human rights'. ${ }^{30}$ As stated by Griffin (2008), 'strong inflationary pressures on the term' human rights 'have brought about its debasement' by rendering it indeterminate in a damaging way. ${ }^{31}$ For their part, Mchangama and Verdirame (2013) have held that if 'human rights were a currency, its value would be in free fall', because when 'everything can be defined as a human right, the premium on violating such rights is cheap'. ${ }^{32}$

26 Kaplan (n 9) 204-205. While Brems (n 11) considers that '[m]argin of appreciation techniques are not so much a solution to the universality-diversity problem as a tool for reaching solutions in specific cases' (422), she agrees that the 'technique of a margin of appreciation that allows for variation in the balancing of individual rights and restriction grounds among different states can be very useful on the world level as well' (380). For a different opinion, see Posner (n 20) 138-139.

27 D Clément, 'Human Rights or Social Justice? The Problem of Rights Inflation' (2018) 22 The International Journal of Human Rights 156.

28 TC Pocklington, 'Against Inflating Human Rights' (1982) 2 Windsor Yearbook of Access to Justice 77.

29 Ph Alston, 'Conjuring Up New Human Rights: A Proposal for Quality Control' (1984) 78 The American Journal of International Law 607, 614.

30 A Gutmann, 'Introduction' in M Ignatieff, Human Rights as Politics and Idolatry (Princeton University Press 2001) 12.

31 J Griffin, On Human Rights (OUP 2008) 92-93.

32 J Mchangama and G Verdirame, 'The Danger of Human Rights Proliferation: When Defending Liberty, Less Is More', Foreign Affairs, 24 July 2013, www .foreignaffairs.com/articles/europe/2013-07-24/danger-human-rights-proliferation. 
More particularly, Posner (2014) considers that 'the greater the variety of human interests that are protected' by the human rights system, the more it 'collapses into an undifferentiated welfarism in which all interests must be taken seriously'. ${ }^{33}$ Similarly, Möller (2014) notes 'the phenomenon that increasingly relatively trivial interests are protected as rights', which is present especially in Europe..$^{34}$ In Clément's view, framing 'issues of social justice as human rights is counterproductive because a rights approach fails to address the root causes of social problems' and may undermine 'the power and legitimacy of rights-talk'. ${ }^{35}$ Also Kaplan considers that 'a great variety of social practices other than human rights might provide the basis for realizing foundational egalitarian values' ${ }^{36}$ However, Western universalism has 'difficulty contemplating alternative visions of social justice that are less individualistic and more focused on religion, communities, social institutions, and duties' ${ }^{37}$ Hence, 'alternative approaches to human rights' are largely neglected. ${ }^{38}$

According to Gutmann, the issue of rights proliferation is linked to that of universality because it 'makes it far more difficult to achieve the broad intercultural assent to rights that an international human rights regime requires to be effective' ${ }^{39}$ In line with what is mentioned above, Kaplan notes that, while 'thin societies prefer a human rights framework that offers broad protections for individual choice and that gives the state a large role in enforcing rules', thick societies prefer 'a few core rules that ensure certain minimum standards are met while providing flexibility for local adaptation' ${ }^{40}$ However, this needs to be nuanced in light of the finding by Freedman and Mchangama (2016) that, at least in terms of UN special procedures, not-free and partly free states have increasingly promoted or supported economic, social and cultural rights as well as third-generation rights (solidarity or collective rights), whereas free states' priority generally lies with civil and political rights. ${ }^{41}$ In this way, not-free and partly free states 'indecorously' encourage rights proliferation. They shift away 'the focus from protecting tangible rights of tangible victims

Posner (n 20) 94.

34 K Möller, 'Proportionality and Rights Inflation' in G Huscroft, BW Miller and G Webber (eds), Proportionality and the Rule of Law: Rights, Justification, Reasoning (CUP 2014) 155, 157.

35 Clément (n 27) 158, 165.

36 Kaplan (n 9) 96.

37 Ibid., 104-105, 113, 116.

38 Ibid., 126.

39 Gutmann (n 30) 12.

40 Kaplan (n 9) 70. See also 36-37, 102 and 213.

41 R Freedman and J Mchangama, 'Expanding or Diluting Human Rights?: The Proliferation of United Nations Special Procedures Mandates' (2016) 38 Human Rights Quarterly 164. 
of abuses $[\ldots]$ onto using the human rights matrix to address broader and more abstract issues only tangentially related to human rights' ${ }^{42}$ Arguably, they aim to avoid effective scrutiny and to 'undermine, dilute, or significantly alter the international human rights system'. ${ }^{43}$

To follow up on his concerns, Kaplan proposes to emphasize less 'the newer Western universalist interpretations and additions to the original compendium of rights', so as to 'reduce the risk of human rights inflation sapping broad political support'. ${ }^{44}$ This is important especially as the 'defensiveness' that people in thick communities feel 'may weaken the overall case for human rights - reducing their legitimacy and moral authority'. ${ }^{45}$ Thus, Kaplan notes that 'the populist backlash in the United States and elsewhere can be interpreted as a shift toward thicker elements such as conservative nationalism in reaction to attempts to make society too individualistic and secular universalist' ${ }^{46}$ For example, the ECtHR, 'partly through its own interpretive overreach, which has seen it expand existing rights and invent new ones, is losing credibility in some important member states' ${ }^{47}$ Similarly, Tasioulas (2019) argues that two deviations from the formative aim of international human rights law (IHRL) have 'subverted' it 'from within', namely (i) the failure to stick to the idea that IHRL 'is primarily concerned with giving effect to moral rights [...] rather than either human interests generally or the full gamut of political values'; and (ii) the 'enthusiastic promotion of both the legalisation and, more specifically, the judicialisation of human rights' ${ }^{48}$ According to Tasioulas, 'some of the external frustrations with IHRL - those often ascribed to a "populist backlash" - may themselves be partly explicable as responses to these internal failures'. ${ }^{49}$

Mchangama and Verdirame have critiqued that 'much of the human rights community has [...] shied away from expressing qualms about rights proliferation'. ${ }^{50}$ This is troubling, especially as contemporary criticisms about human rights show important links between the issues of proliferation and universality, and suggest that proliferation may have contributed to the so-called 'backlash' against human rights. In this light, Chapter 6 by Kasey McCall-Smith introduces the topic by outlining the different types of rights proliferation.

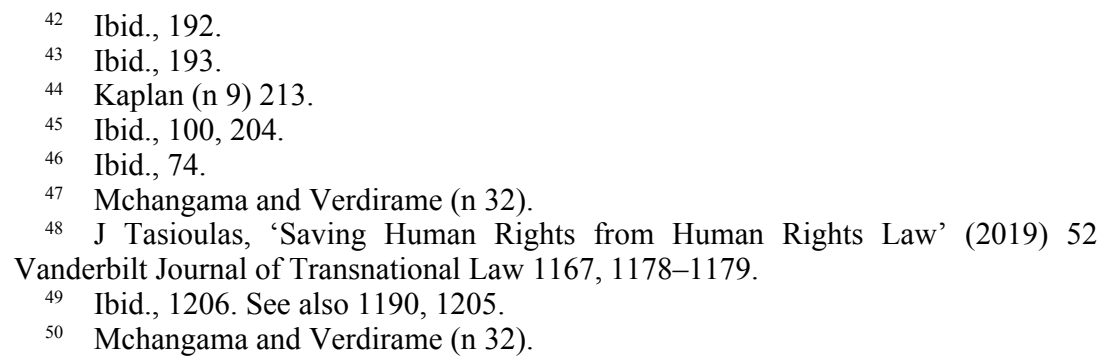


Chapter 7 by Dalia Palombo zooms in on the role of human rights adjudication in the proliferation of and backlash against human rights. Focusing on sustainable development, Chapter 8 by Michelle Meulebrouck takes up the suggestion mentioned above to explore alternatives to the human rights language, but shows how dealing with (alleged) human rights issues through alternative approaches may result in a loss of protection and fragmentation. With an analysis of how the ECtHR deals with denationalization measures, Chapter 9 by Louise Reyntjens shows how the recognition of a new right - the right to a nationality - may not be necessary if existing rights are adequately applied.

\subsubsection{Costs}

A last topic addressed by this volume, and which is interdependent with the topics of universality and especially proliferation, is that of the costs of human rights. All human rights, and especially economic and social rights, are costly. ${ }^{51}$ When talking about costs, we primarily mean budgetary or economic costs. Still, rights also have nonmonetary costs, notably including social costs (e.g. the harm inflicted on private individuals by criminals who were released on human rights grounds), ${ }^{52}$ political costs (e.g. the electoral costs public authorities face when deciding to take positions in favour of or against human rights), ${ }^{53}$ as well as cultural costs (referring to the extent to which cultures are required to adapt or give up certain traditional practices or values in favour of human rights).

As noted by Holmes and Sunstein (1999), the fact that human rights are costly implies that 'the political branches, which extract and re-allocate public resources, substantially affect the value, scope, and predictability of our rights'. ${ }^{54}$

First, it is worth making explicit that 'rights protection is funded by the ordinary taxpayer', which 'helps us see clearly that rights are public goods: taxpayer-funded and government-managed social services designed to improve collective and individual well-being, ${ }^{55}$ Relatedly, Holmes and Sunstein propose to understand rights as bargains in the context of a 'social contract' that uses 'rights to enhance mutually beneficial social cooperation' ${ }^{56}$

51 'Righting Wrongs', The Economist, 18 August 2001, 18-20; Tasioulas (n 48) 1203-1204; Donnelly (n 14) 42.

52 S Holmes and CR Sunstein, The Cost of Rights: Why Liberty Depends on Taxes (WW Norton \& Company 1999) 15-16, 21-22.

53 Cf. Posner (n 20) 103.

54 Holmes and Sunstein (n 52) 30-31.

55 Ibid., 21, 48.

56 Ibid., 175-188. 
In this vein, Chapter 10 by Felipe Gómez Isa argues that the duty to pay taxes must be seen as a duty of solidarity connected to a new social contract that responds to the contemporary challenges to human rights. In particular, the contract must recalibrate 'the balance between the market, the state and other stakeholders that has been reversed by the current process of globalization'.

Second, taking 'rights seriously means taking scarcity seriously', as attention 'to the costs of rights reveals the extent to which rights enforcement [...] is shot through with trade-offs, including monetary trade-offs' ${ }^{57}$ As noted by Posner, the proliferation of human rights highlights this problem: 'when there are hundreds of rights, states must make complex tradeoffs' ${ }^{58} \mathrm{He}$ warns that as human rights treaties 'do not explain how one is to make tradeoffs', governments simply 'fall back on making tradeoffs based on their conception of the public good', following which human rights 'render each other meaningless for constraining behavior'. ${ }^{59}$ Also according to Clément, proliferation has resulted in an 'impossible aspiration of guaranteeing all grievances that are today framed as human rights' and 'forces states to make impossible choices using limited resources'. ${ }^{60}$ Similarly, Tasioulas objects to the assumption that any 'egalitarian ideal is the proper business of IHRL on the illusory basis that everything of great value reduces to human rights'. ${ }^{61} \mathrm{He}$ warns that rights that are 'readily and systematically overridden by competing considerations, given an environment of multiple competing claims on scarce resources' may result in 'intense frustration when these entitlements are not remotely satisfied' and thus breed 'scepticism about human rights law'. ${ }^{62}$

The issue of scarcity and trade-offs, as exacerbated by proliferation, is particularly pressing in developing countries. Posner considers that as human rights 'treaties provide no guidance as to how resources should be allocated' and human rights law 'suffers from the problem of rule naiveté', it should abandon its 'utopian aspirations' and start 'learning the lessons of development economics'. ${ }^{63}$ Thus, funds should be used 'in ways that do the most good' and with 'sensitivity to local conditions', 'not to compel the country to submit to an abstract formulation of human rights that Westerners imagine are right for everyone in the world' ${ }^{64}$ Connecting the issue of costs to that of universality in a similar way, Kaplan argues that in 'developing countries, eco-

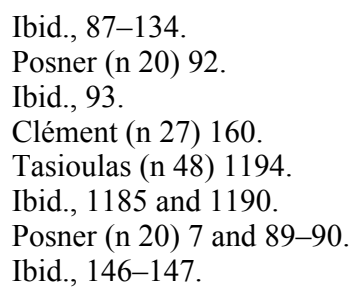


nomic and social needs may need to be balanced alongside civil and political rights': 65 'some individual rights may have to be curtailed, modified, or even suspended in some contexts in order to create the most effective total system to advance a community's overall goals (only some of which will involve rights) and to maximize the exercise of rights over the long term' ${ }^{66}$ Tasioulas, in turn, argues that certain doctrines, 'such as those of progressive realisation and minimum core obligations, which offer guidance with respect to the prioritisation of human rights demands in the face of resource scarcity', should be developed more fully ${ }^{67}$ But overall, in this respect, 'development economics is a far superior source of guidance than IHRL ${ }^{6}{ }^{68}$ In this light, Chapter 11 by Gustavo Arosemena and Bart Kleine Deters aims to provide tools for resolving trade-offs that need to be considered under a human rights-based approach to development. Chapter 12 by Dina Townsend and Nicky Broeckhoven uses the example of Ethiopia to illustrate that a straightforward cost-approach to human rights may not adequately take into account the cost of generating the means to pay for rights.

Third, Holmes and Sunstein observe that 'cost-consciousness in the field of rights enforcement presents a serious challenge to the judiciary, $[\ldots]$ because it demands attention to a broad range of competing demands upon the public budget, while judges are necessarily riveted to a particular controversy' ${ }^{69}$ Posner adds: 'How to allocate resources among the various needs and demands is a political question, or at least not one that lends itself to judicial involvement' ${ }^{70}$ According to Tasioulas, there are 'significant limitations on the idea of strong justiciability in relation to human rights claims' ${ }^{71}$ In particular, the wealthy 'are better placed to exercise their human rights entitlements', following which 'more scarce resources are used to benefit better-off people' ${ }^{72}$ Moreover, judicial law-making is not democratic, which according to Tasioulas "risks fuelling the "populist" charge that human rights are playthings of "elites" ${ }^{73}$ Given their distance from domestic jurisdictions, all of this applies 'with even greater force to regional or international courts' ${ }^{74}$ Also Chapter 13 by Hillel Sommer finds that courts are not well positioned to take

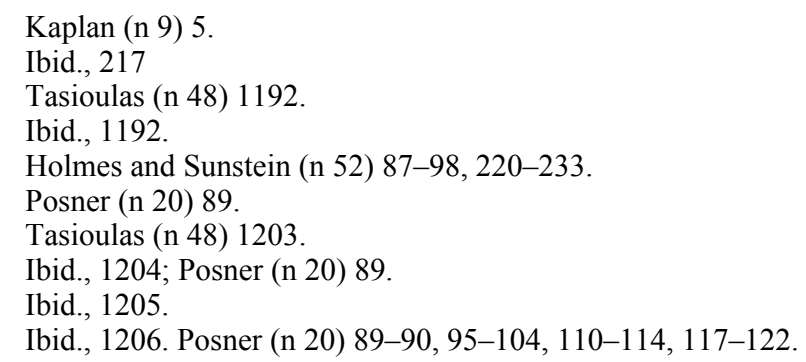


costly human rights decisions, and formulates a number of propositions to remedy this issue.

Figure 1.1 aims to summarize the theoretical background outlined above in a way that visualizes the links between the issues of the universality, proliferation and costs of human rights. It focuses on the extreme positions associated with each issue, as well as on the typified characteristics of the societies or communities associated with such positions. To put it in a simplified manner, thin, free and developed societies would typically favour (Western) universalism and rights inflation, for which they are able and willing to pay high costs. Thick, non-free and developing societies, on the other hand, would typically favour a relativist approach and a limited core of human rights obligations, considering that they are not willing and/or able to pay for the full spectrum of human rights, or at least not in the way they are conceived and interpreted by the first group of societies. Needless to say, the figure depicted is stylized, and societies may tend towards different combinations of extremes. Still, it may help to grasp the interdependency of the issues mentioned above and the way the contributions of this volume illustrate it. The latter will be outlined in the next part, which respectively deals with aspects of (i) universality and proliferation, (ii) universality and costs and (iii) proliferation and costs.

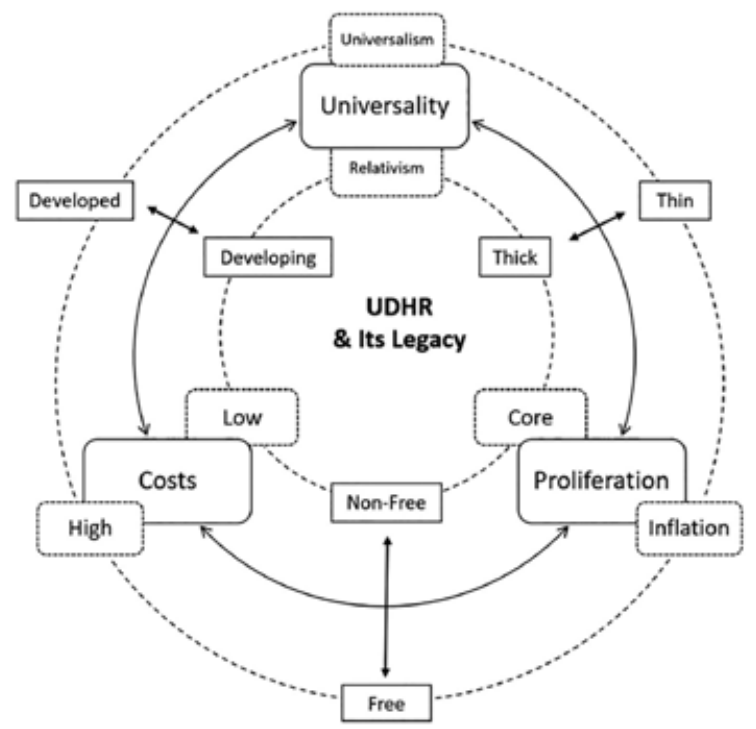

Figure 1.1 The interdependence of issues relating to the universality, proliferation and costs of human rights 


\subsection{THE CHAPTERS IN THIS VOLUME}

\subsubsection{Universality and Proliferation}

In Chapter 2 Nick Goetschalckx introduces the theme of universality. Relying on the drafting history of the UDHR, he shows how human rights have been conceived based on fundamental tenets of humanity that are grounded in different moral, religious and philosophical beliefs, without connecting those tenets to a god or nature. Accordingly, the UDHR is neither fully universal, nor fully relative, but both: human rights are characterized by a 'relative universality'. This being noted, Nick Goetschalckx advocates unlocking the full potential of the UDHR and its legacy by settling the universalist-relativist debate and accepting human rights' 'presumptive universalism': universality is presumed, unless sufficient elements point to relativism.

Goetschalckx shows how the UDHR was drafted based on an overlapping consensus between different cultures and beliefs as regards the defining tenets of humanity. By minimizing the philosophical depth of the foundation of human rights, substantive agreement was facilitated and unnecessary hurdles were avoided. Thus, quoting Frédéric Mégret, the author sees the UDHR as a 'meeting ground rather than a definitive program', ${ }^{75}$ providing space for a process of global public deliberation. This process has led to the adoption of a rich body of international human rights treaties, as well as other human rights instruments, which in turn provide meeting grounds for further public deliberation. This deliberative process is crucial for achieving the overlapping consensus that makes human rights 'relatively universal'. Considering the proliferation of human rights, achieving this overlapping consensus may become difficult where new human rights or interpretations thereof stand further from the fundamental tenets of humanity than the rights laid down in the UDHR. Precisely this proliferation may tempt some to rebut Goetschalckx' presumption of universality in favour of relativism.

The interdependence between universality and proliferation also features in Chapter 3, in which Konstantinos Magliveras argues that arguments of cultural relativism should not be allowed to serve as an excuse to curtail the enjoyment of a core of universal human rights. To ensure the human rights system's longevity and effectiveness, he tackles the issues of universality and proliferation by proposing to replace the so-called core UN human rights conventions and their treaty bodies by one comprehensive, global convention with a single treaty body. Noting that not all core human rights conventions have been rati-

75 Frédéric Mégret, 'International Human Rights Law Theory' (2010) SSRN, papers.ssrn.com/sol3/papers.cfm?abstract_id=1539591, at 7 . 
fied by all states, he argues that the comprehensive convention should consist of a core part reflecting a minimum of rights to be accepted by all states, as well as thematic protocols containing specific rights or group rights, to which states may choose to subscribe, as a way to accommodate particularist claims.

In Chapter 4, Paul Lemmens notes that the 'common understanding' of human rights as referred to by the UDHR is helped by the cross-referencing amongst supervisory bodies like the UN Human Rights Committee and the ECtHR. However, the idea of a universal understanding is not determinative of the ECtHR's decisions, especially where it has established case law. The different regional human rights systems may to a large extent use the same wording, but at the same time express values in terms adapted to their regional situation. In this vein, the ECtHR considers the ECHR to be a living instrument that can be interpreted and adapted to current circumstances - a tree that develops, but whose roots remain attached to the ground.

As shown in Chapter 5 by Johan Lievens and Nele Verbrugghe, within the Council of Europe, the ECtHR may advance universality by expanding rights realizations that are present in a sufficient number of Council of Europe member states to other member states (i.e. the consensus doctrine). The Court does so by means of interpretations that bring such rights realizations into the protective realm of relevant ECHR provisions. Thus, 'regional universality' is realized bottom-up, by means of rights proliferation.

In Chapter 6, Kasey McCall-Smith uses the example of reservations to human rights treaties to illustrate that in the context of proliferation, a pragmatic or 'calculated' position will usually aim for universal participation. It will pursue a communitarian approach that includes as many states as possible to entrench global human rights governance, also when new human rights instruments are adopted. Human rights devotees, on the other hand, may stress that the integrity of the human rights system should be preserved, and argue that those who do not want to implement human rights in a meaningful way should be excluded. McCall-Smith argues for an 'enlightened pragmatism', which pursues a calculated approach that is informed by considerations of ethics and justice.

Further, she shows how the marked proliferation in human rights instruments and accompanying monitoring bodies has resulted in a global human rights system that 'enables states to adhere to distinct human rights regimes in concert with the evolution of their unique societies'. These instruments have given us a global frame of reference, a globally unified vocabulary to define and redress assaults on human dignity. Whilst respecting the treaties' permissions as to rights limitations, the UN treaty bodies define minimum standards that should be ensured globally. In line with Paul Lemmens, Kasey McCall-Smith takes the view that the increasing references by national courts to human rights treaties and their interpretations by treaty bodies or regional 
human rights courts advance the incremental development of common human rights standards.

Lastly, McCall-Smith notes that advocates pursuing personal human rights interpretation and promotion may create 'localized' human rights interpretations. At the same time, the cumulative effect of such processes may be that specific human rights language gets noticed more broadly and that these interpretations take root and make the international system evolve. Still, human rights devotees should be wary that when their agenda becomes that of a 'liberal-democratic civil religion', the clash with competing agendas may result in negative impacts on entrenching human rights. Enlightened pragmatism is required to best advance human rights' universal cause; otherwise, rights proliferation is too easily set aside negatively as rights inflation.

In Chapter 7, Dalia Palombo discusses the hopes and failures of human rights adjudication. From the hopes perspective, she writes that human rights are considered to be inherent to any human being and 'apply everywhere in the world as part of one universal legal system'. The failures perspective, on the other hand, tells us that rights proliferation has come with fragmentation, as illustrated by the fact that states are free (not) to ratify (new) human rights treaties or to make reservations to them, as well as by the fact that the three regional human rights treaties (namely the African Charter on Human and Peoples' Rights, the American Convention on Human Rights, and the ECHR) reflect the specificities of their respective regions, and that human rights courts emerged at the regional rather than international level.

According to Palombo, the unfulfilled promises of human rights have triggered two different responses: (i) one that recuses human rights as a tool for social change, and argues that a new language needs to be invented to fight social injustices; and (ii) an approach that has embraced the human rights rhetoric and uses it to advance social change. The latter approach has, amongst others, relied on human rights adjudicatory bodies as a tool to achieve envisaged changes. As also highlighted by McCall-Smith, these adjudicatory bodies have relied on a range of interpretative techniques to expand the scope of the instruments whose implementation they monitor, and thus also their jurisdiction. However, when adjudicating, they oscillate between hopes and failures. They pursue universal aspirations, but they can never really escape the fact that they are embedded in a state-centric system and (must) often take into account the broader costs a particular interpretation of a human right entails for a state and its society.

Relatedly, some argue that 'judicial activism' has turned human rights into a politicized, and even 'undemocratic' instrument of a 'leftist' agenda, imposing 'supposedly' universal values that entail significant costs. Moreover, the state has become the victim of the state-centric model: the more states accept human rights obligations, the more they become the target of human rights 
claims. Thus, states may opt to 'isolate' themselves from the human rights system, because the political costs of adhering to it increase and may become too high. But if human rights lose the support of states, this will trigger the failure of the human rights system. Even if they aim to become a universal tool for change, inevitably, human rights depend on states' will. Thus, eventually, the human rights story is, and can only be, 'a circular plot of hopes and failures that slowly but firmly develops further'.

Chapter 8 by Michelle Meulebrouck takes up an issue hinted at by Palombo, namely whether resort has to be had to alternative languages rather than human rights to fight social injustices. Focusing on EU trade agreements, Meulebrouck examines whether the sustainable development paradigm contributes to a globally unified human rights vocabulary as mentioned by Kasey McCall-Smith, or rather to fragmentation of the human rights language. She concludes that at least within the context of EU free trade agreements, it risks eroding human rights protection. Furthermore, Meulebrouck argues that also in the context of free trade agreements, a human rights-based approach to development (on which see Chapters 10-12) should prevail. Following such an approach, the inclusion of a sustainable development approach in trade agreements can be a factor of integration rather than fragmentation. Overall, Meulebrouck's chapter suggests that human rights cannot easily be replaced by alternative notions or discourses, and that they may well be an inescapable means to fight social injustices.

In Chapter 9, Louise Reyntjens examines the issue of proliferation from a different perspective. Noting European states' increased reliance on denationalization as a tool in the context of the recent migration and security crisis, she examines whether or not the European human rights system is in need of a new, autonomous right to a nationality. While Reyntjens comes to the conclusion that this right is currently insufficiently protected by the ECHR, she shows that effective human rights protection is not necessarily correlated with the proliferation of rights, or at least not with the recognition of new rights. She finds that is not necessary to create an autonomous human right to a nationality, provided that the building blocks of such a right that are already in place under different human rights enshrined in the ECHR are effectively applied.

\subsubsection{Universality and Costs}

Underlying the drafting process of the UDHR and any codification of human rights is an evident and inevitable political process. Thus, Nick Goetschalckx in Chapter 2 highlights the difference between moral and positive human rights: while everyone is entitled to certain moral rights based on ethical claims, one only has rights once they become positive by being legislated upon. This distinction informs the debate on the costs of human rights: while 
the entitlement to certain rights may certainly be presumed to be universal, the extent to which these rights become positive is influenced by a political reality involving scarce resources, inequalities and competing interests.

This political reality is also recognized by Magliveras in Chapter 3. When making his proposal to replace the core UN human rights treaties by one comprehensive, global human rights convention, he argues that it could be wise to exclude certain states. ${ }^{76}$ States with a very poor human rights record, being states that are unwilling or unable to implement the convention, should not benefit from the international legitimization attached to their ratification thereof. Magliveras believes that such an approach is preferable to the current situation, in which some states (are allowed to) accept being bound by human rights norms even if they are not willing and/or able to pay the price. At the same time, Magliveras proposes to make it more costly to violate human rights, so as to ensure their implementation. He argues that the Assembly of States Parties to be established in conjunction with his proposed global convention should be able to impose punitive measures upon recalcitrant states that go further than mere 'naming and shaming', and that could be monetary in nature.

As to the implementation of human rights, Lemmens notes in Chapter 4 that while the UDHR and ECHR took human rights out of the exclusive sphere of domestic jurisdiction, implementation primarily lies with the domestic authorities, while supranational bodies like the ECtHR play a subsidiary role. Domestic authorities are in principle in a better position than supranational judges to assess interferences with human rights - subject to European supervision. Thus, they enjoy a certain margin of appreciation, the breadth of which depends on the circumstances of the case and can be narrowed by the existence of a European consensus.

The 'consensus' and 'margin of appreciation' doctrines of the ECtHR, and their link with the costs of human rights, are very well illustrated by Lievens and Verbrugghe in Chapter 5. They show how the ECtHR approaches moral diversity in a way that takes into account deep-rooted social and cultural traditions. In doing so, they highlight the Court's balancing exercise between competing demands of individual and social morality, ${ }^{77}$ or between minority lifestyle choices and mainstream community principles. ${ }^{78}$ As long as the

76 Adhering to a devotee, rather than a calculated approach: the two 'extremes' between which Kasey McCall-Smith argues one should find a balance in the form of 'enlightened pragmatism'; see Chapter 6 of this volume.

${ }^{77}$ P Johnson, 'An Essentially Private Manifestation of Human Personality: Constructions of Homosexuality in the European Court of Human Rights' (2010) 10 Human Rights Law Review 67, 77.

78 C Draghici, The Legitimacy of Family Rights in Strasbourg Case Law: 'Living Instrument' or Extinguished Sovereignty? (Hart 2017) 192. 
ECtHR considers that the (perceived) socio-cultural costs for the majority are too high, in cases of extending the protection offered by the ECtHR, these costs will constitute one of the reasons for which the Court may follow a relativist rather than universalist approach, halting relevant progressive interpretations - or the proliferation - of human rights and giving states a margin of appreciation. This approach, so the authors submit, can be questioned in light of 'the anti-majoritarian' role of human rights, and the rather arbitrary way in which the ECtHR applies its consensus and margin of appreciation doctrines. Still, Lievens and Verbrugghe note that the Court depends on national governments to implement its decisions and accordingly to ensure the effectiveness of the ECHR. Relatedly, maintaining its legitimacy is an important concern for the Court, which also plays a role in the sustainability of human rights. In this light, the authors take the view that the Court has managed to find a middle ground between the diverging views as to same-sex relationships, or in other words, that it has rightly balanced considerations of universality on the one hand and socio-cultural costs on the other.

In Chapter 10, Felipe Gómez Isa shows how economic considerations are not necessarily at odds with human rights. Human rights, and especially economic and social rights, have been considered to fly in the face of liberal market economies, while in particular civil and political rights have been perceived as obstacles for economic growth by developing countries. However, in the 1980s and 1990s, human rights became central to a more comprehensive and multidimensional conception of development: 'human development'. The realization of human rights may be costly in the short run, but positively affects economic growth and development in the long run. Thus, arguments that human rights are something for rich nations because they have the means to pay for them are flawed, at least in the long run. The fact that human rights benefit economic growth and development strengthens the argument that their realization should be aspired to universally, by all states, including developing countries.

In Chapter 11, Arosemena and Kleine Deters note that scholars and activists in the field of rights-based development 'often prefer to emphasize the possibility of a better world for everyone than to dwell on the fact that that world is not immediately achievable and that divisive choices need to be made'. This entails risks for human rights: they may be dismissed as a mere slogan, or become a discourse that is displaced by those having to make the cost-benefit analysis. Thus, the authors provide a taxonomy of the conflicts or trade-offs that exist in rights-based development, and explore the tools that decision-makers have to deal with these trade-offs.

One of the trade-offs evoked in their chapter informing the relation between costs and universality is that of 'realization versus equality': sometimes, it may be more efficient to improve the human rights situation generally rather 
than to target disadvantaged groups specifically, or vice versa. Similarly, the trade-offs between 'non-retrogression versus realization' and 'non-retrogression versus equality' may require regression of human rights enjoyment by some in order to attain a more general satisfaction (realization) or a more equal enjoyment (equality) of rights. Thus, even if (moral) human rights are universal, the reality of their costs obliges us to make hard choices about their (positive) fulfillment, lest human rights are dismissed as a mere façade for economic calculation, albeit now presented with a human face.

Also in Chapter 12, Townsend and Broeckhoven highlight that, for developing countries, human rights may create a heavy financial burden. Focusing on Ethiopia, they show how the country has invested enormous amounts of money in improving Ethiopians' quality of life and their human rights situation, at least as regards economic and social rights. Equally, the authors demonstrate that pursuing rapid economic growth and development may come at a considerable human rights cost. In Ethiopia, civil and political rights, as well as certain environmental rights, have been considered to stand in the way of the realization of social and economic rights. Thus, some (developing) states put certain human rights and democracy aside, so as to prioritize modernization and economy building. However, in doing so, they may fail to take into account the costs associated with ignoring certain human rights. In the case of Ethiopia, the massive leasing of land to (foreign) investors entails considerable costs, in the short as well as in the long run.

Framing it in the language of the chapter by Arosemena and Kleine Deters, Ethiopia's policy has resulted in a rights trade-off, not only between different categories of rights (economic/social rights versus civil/political rights), but also between different segments of the population (original land occupiers versus migrant workers). However, there is little evidence that any trade-off between civil and political rights on the one hand, and economic and social rights, or development more generally, on the other, is necessary. The contrary is rather the case: civil and political rights precondition and enable economic development and may result in greater economic growth. Moreover, any violation of civil and political rights entails economic costs in itself (e.g. incarceration), as well as an intrinsic socio-cultural cost that is incommensurable. Development should therefore not only be measured in economic, but also in social, political, cultural and environmental terms.

The political reality underlying the distinction between moral and positive human rights implied by Goetschalckx is further highlighted by Sommer in Chapter 13, in relation to the right to health. Sommer analyses the institutional suitability of the judiciary to make costly human rights decisions, focusing on costly medical procedures. In such procedures, the judiciary takes decisions that may be expensive and imply that other budgets have to be cut. Thus, Sommer finds that the executive and legislative branches of government are 
better equipped to make such decisions, as they take into account the 'bigger picture'. To the extent that courts take such decisions, they should be fully aware of their short- and long-term budgetary effects, and possibly be limited in their spending power. Much like Chapters 11 and 12 do for development situations, Sommer's chapter shows that the cost of human rights necessarily affects the extent to which the right to health can be fully realized universally.

Lastly, like Goetschalckx and Lemmens, in the concluding chapter, Dima Yared takes an overall perspective when stressing that we should continue to carry the costs of human rights principally because of 'the human in human rights; the human to which the rights attach'. Human rights encapsulate 'common aspirations across humanity, not unique to one specific group of people or religion or philosophy'. Therefore, 'investing in human rights means investing in what unites us as a global community'.

\subsubsection{Proliferation and Costs}

A first observation on the interdependence of the issues of costs and proliferation is made by Magliveras in Chapter 3, when he advocates for a single, global human rights treaty with a singly treaty body. The reasons for his proposal include that much of the work of the treaty bodies is duplicated, while their operation as separate bodies is a costly matter, continuously facing the challenge of budgetary cuts.

Further, as discussed above, an expansion of the protective realm of ECHR provisions may depend on the achievement of a consensus amongst a sufficient number of Council of Europe member states as regards a particular matter. This cautiousness in regard of progressive interpretations of the ECHR is, at least in part, informed by the (perceived) socio-cultural costs such interpretations may inflict on those Council of Europe member states where rather conservative views and traditions are prominent. Thus, such costs may inhibit, or at least halt, the proliferation of human rights, as incautiously achieved proliferation may affect the Court's legitimacy among (such) member states.

On the other hand, McCall-Smith points out in Chapter 6 that (legal, linguistic and evolutionary) proliferation of human rights should not be considered as a negative phenomenon, but rather as a way to balance 'devotion to human rights with political and economic calculation'. However, she highlights that as states are more and more often confronted with claims to positive obligations, economic realities will increasingly direct their future priorities. In line with Magliveras' argument mentioned at the beginning of this section, McCall-Smith recognizes that the multiplication of human rights instruments and monitoring mechanisms has resulted in a treaty and reporting 'fatigue', which creates a burden especially on smaller or developing countries with limited resources. While the overloading of human rights monitoring 
mechanisms with complaints may be a relatively costly affair, it proves that individuals around the globe are claiming their rights.

At the same time, McCall-Smith warns for what she calls the 'casualization' of human rights, which may 'distort the legal meaning and lead to slippage in the understanding of a right or suggest that human rights vocabulary, in a legal sense, may apply to any desire created by the human heart'. Human rights advocates often emphasize the vocabulary serving their cause, but should be wary of the costs they inflict on (the rights of) others. They should be careful with human rights claims 'that may fly in the face of the vast majority of society' (cf. above, on socio-cultural costs), or that 'demand great financial output to support a small number of people (or even one person) rather than providing greater protections for a larger number of people' (cf. above, on trade-offs). This may trigger push-backs against 'devotees' in different positions. Again, the approach proposed by McCall-Smith to deal with such situations is enlightened pragmatism, especially considering that every 'human rights situation' is contingent upon a culmination of factors that will never look the same at any point in time. Lastly, the author also discusses the expansion of human rights obligations of states outside their territory, as well as the issue of corporate human rights obligations. While it may be costly for corporations to (fully) respect human rights and abuses continue to abound, it may - and should - also be costly for them not to respect human rights.

In Chapter 7 Dalia Palombo explains that the proliferation of human rights may not simply broaden human rights protection, but also have an impact on the legitimacy of human rights systems, and result in effects unwanted by the human rights activists at the basis of this proliferation. As also pointed out by Lievens and Verbrugghe, to maintain their legitimacy and that of the human rights system as a whole, (human rights) courts need to cautiously balance the costs and benefits of rights extension. Relatedly, Palombo highlights the multiple layers of accountability that have been created by the proliferation of human rights instruments. Needless to say, the accountability vis-à-vis the public - and the associated political cost - is higher for states that are party to a higher number of human rights instruments. Such states 'may even bear an accountability burden for the benefits of others that are not willing to comply with human rights'. Quite obviously, this disincentivizes states from joining human rights instruments, and may even incentivize states to leave such instruments.

Taking into account the arguments of critics of human rights proliferation, Reyntjens argues in Chapter 9 that the lack of protection of the right to a nationality does not necessarily imply that the creation of an autonomous right is needed. If the ECtHR interprets the rights that are explicitly enshrined in the ECHR, and notably the right to a private and family life and the prohibition of discrimination, in a way that results in an effective protection of the 
right to a nationality, the creation of a new right is unnecessary, and the costs attached to that instance of human rights proliferation can be avoided.

Gómez Isa makes it clear in Chapter 10 that, owing to the proliferation of human rights, their realization has become an increasingly sophisticated and costly matter, laying claim to a large part of public expenditure. Thus, he argues that in order to maintain the legitimacy of human rights, considerations of costs, efficiency and social utility need to be taken into account. For such purposes, human rights indicators represent essential tools. Relatedly, and as mentioned above, Gómez Isa advocates for a human rights-sensitive fiscal policy, conceiving the duty to pay taxes as one of solidarity. Tax rates should be high enough and progressive, to foster the implementation of human rights, and especially economic, social and cultural rights.

As mentioned above, in Chapter 11 Arosemena and Kleine Deters provide a taxonomy of the trade-offs that exist in rights-based development. One such trade-off that sheds light on issues flowing from the proliferation of human rights is that of 'realization versus realization': considering that resources are finite and that the realization of human rights requires resources, any evolved or new human right requires resources that cannot or can no longer be spent on other, previously existing human rights. Also, if the realization of human rights becomes too costly, a conflict of 'competing non-retrogression' may arise, meaning that a choice has to be made between regressions of human rights realizations to the detriment of some human rights beneficiaries. Relatedly, Townsend and Broeckhoven underline in Chapter 12 the fact that, when the protection of new rights is implemented, enough attention should be paid to 'the cost of generating the means' necessary to this implementation. In other words, the way in which resources, able to provide a broader protection of human rights, are generated, should not result in a breach of (other) human rights.

Sommer notes in Chapter 13 that besides costly medical procedures, other matters concerning large amounts of public expenditure (e.g. decisions regarding the organization of prison systems) have become issues that are adjudicated in court. The more such matters and specific cases are brought within the purview of positive human rights adjudication, and the more courts adopt expansive human rights interpretations, the costlier the realization of human rights becomes. Such court rulings are expensive, and the scarcity of resources implies that such expensive choices can only be realized through budgetary cuts in competing programmes or by increasing taxes. Moreover, there is a political cost: arguably, expensive human rights decisions by courts are less democratic than budget allocations by the legislative and/or executive branch of government (although, of course, human rights law puts limits to the discretionary powers of the legislative and executive branch in this respect). However, as mentioned above, according to Sommer, courts' finan- 
cial accountability can be improved by raising awareness of the budgetary consequences of their decisions and by limiting the budgetary expenditure judgments can impose.

In the concluding chapter, Yared aptly describes the 'human rights backlash', which according to some has been caused by human rights proliferation. First, she quotes Palombo, who writes:

Jurisprudential activism has necessarily politicized human rights, which are no longer viewed as universal values coming from the sky, but instead as political, and potentially harmful, tools that activists use to advance a certain political agenda.

Some states have felt 'under attack' and have denounced human rights instruments or fora, pulled out of them and actively engaged in a retreat from human rights protection through legislative changes in various domains. Even traditionally human rights-friendly political parties have engaged in anti-human rights discourse. This backlash is based on the presumption that the costs of human rights are, or have become, too high. Yared admits that there are costs to human rights: they require economic investment as well as social and political commitment. Nevertheless, the realization of human rights will result in economic as well as broader societal benefits, in areas such as gender equality and climate change. Building on these two examples, Yared agrees with Gómez Isa: while human rights may require different types of investments and commitments, 'the costs of inaction or improper, short-sighted action, are too high'.

\subsection{CAN WE STILL AFFORD HUMAN RIGHTS?}

Goetschalckx argues that 'in the context of global challenges to human rights and humanity, the question is not whether we can still afford human rights though whether we can still afford to ask this very question'. He refuses to be locked in an intellectual cage, like that of universalism or relativism, but advocates a pragmatic 'way out' to reinvigorate the human rights project. $\mathrm{He}$ defends a human rights utopia inspired by a revived commitment to human rights, as emancipated by a 'presumptive universalism'. By putting humanity at the centre of international law and politics, the UDHR and its legacy should be 'mythicized' and firmly embedded in the belief system of international law to empower the international legal order. This view translates the 'hopes narrative' described by Palombo, according to which human rights are 'truths', 'deriving directly from the notion of "human being", and therefore able to affirm themselves as a utopian project at a universal level'.

Similarly, Gómez Isa argues that the 'question to be answered is not whether or not modern states can afford human rights, but whether or not our socie- 
ties can afford not to realize human rights'. Considering that the price to be paid for non-realization is too high, the answer is no. Still, globalization has resulted in inequalities and provided fertile ground for populists challenging long-accepted human rights realizations. Therefore, Gómez Isa argues for a new social contract between citizens and their state that redefines the balance between the market, the state and other stakeholders, and that envisages putting an end to inequalities and provides the basis for the full realization of human rights. Also McCall-Smith concludes by saying that 'rather than questioning the "need" for human rights, we should be questioning the way in which we promote, protect and fulfil those rights'.

Yared argues that the mere fact of asking whether we can still afford to protect those in need of human rights protection strips them of agency and further de-humanizes them. Still, according to Yared, we should have 'hard discussions about why investing in human rights matters', including with those who disagree. Also Arosemena and Kleine Deters stress the need for such discussions in relation to development. While they agree that we can still afford human rights, they stress that human rights advocates should go beyond the dogma that human rights are 'indivisible and interdependent' and beyond a partisan approach, comparable with what McCall-Smith calls a 'devotee approach': an approach assuming that all rights can exist in full harmony, and neglecting that where there are winners, there may also be losers. Thus, to avoid human rights being dismissed as utopian or even deceitful, human rights advocates must address conflicts between rights (holders). Similarly, Townsend and Broeckhoven address the need to pay attention to the costs of realizing human rights, and argue that one should not fail to take into account how to generate the means or the wealth required to pay for human rights. The same idea underlies Sommer's chapter about the judiciary's aptness to take expensive human rights decisions.

One author questions the effectiveness and sustainability of the UDHR's legacy more fundamentally. Magliveras argues that the proliferation of UN human rights conventions has led to a sub-optimal system characterized by much duplication. He believes that a 'breath of fresh air' is required, in the form of a new, comprehensive and global UN human rights convention, considering that 'the fact that the success of a project is not guaranteed is not a reason not to attempt it'. However, most authors, like Yared, put emphasis on the need to 'build on the achievements made to date'.

The central tenet of the authors' contributions is the need for a renewed and lasting commitment to human rights. Starting from such commitment, the question 'Can we still afford human rights?' is generally turned around and phrased in the negative. Issues relating to the universality, proliferation and costs of human rights, especially when looked at in an interdependent way, show that the human rights project suffers from considerable deficiencies, and 
that it is in need of more calculation. At the same time, examining these three interdependent issues shows that for those who believe in humanity, there is no equivalent alternative. We cannot afford not to afford human rights. 